portant, therefore, to find out.when the maximum average density, or what is practically the same thing, the maximum barometric weight of this stratum, occurs, and more especially to see whether it coincides with the epoch of minimum temperature, which, as a rule, occurs in Tanuary throughout India.

The following table, in which I have calculated the mean

\begin{tabular}{|c|c|c|c|c|c|c|c|c|c|c|c|c|}
\hline \multirow{2}{*}{\multicolumn{3}{|c|}{ Stations. }} & \multirow{2}{*}{\multicolumn{3}{|c|}{$\begin{array}{l}\text { Elevation above } \\
\text { sea-level in } \\
\text { feet. }\end{array}$}} & \multicolumn{7}{|c|}{ Mean monthly barometric pressure in inches. } \\
\hline & & & & & & $\begin{array}{l}\text { October. } \\
\text { I9.714 }\end{array}$ & $\begin{array}{l}\text { November. } \\
707^{*}\end{array}$ & $\begin{array}{c}\text { December. } \\
7728\end{array}$ & $\begin{array}{c}\text { January. } \\
.553\end{array}$ & $\underset{57 \mathrm{I}}{\text { February. }}$ & $\begin{array}{l}\text { March. } \\
.656\end{array}$ & $\begin{array}{l}\text { April. } \\
\cdot 630\end{array}$ \\
\hline Lahore & $\ldots$ & $\ldots$ & $\ldots$ & $73^{2}$ & & $29^{\circ} \mathrm{I} 44$ & $\cdot 262$ & 332 & $\cdot 243$ & $\cdot 237$ & .107 & 28.962 \\
\hline Stratum & betwe & $n-t h$ & kness & 10, 806 & weight & $9^{\circ} 43^{\circ}$ & 555 & $\cdot 604$ & 690 & 666 & $45^{1}$ & $33^{2}$ \\
\hline Chakrata & $\cdots$ & ... & $\cdots$ & 7,052 & & $23: 332$ & $\underline{356}$ & 352 & 304 & $\cdot 313$ & $\underline{325}$ & 309 \\
\hline Roorkee & $\cdots$ & $\cdots$ & $\cdots$ & 887 & & $28 \cdot 965$ & $29 \overline{102}$ & .150 & $\cdot 108$ & 050 & $28 \overline{965}$ & 853 \\
\hline Stratum & betw & $n-t h$ & cliness & 6,165 & weight & 5.633 & 746 & 798 & .804 & 737 & $\cdot 640$ & '544 \\
\hline Darjeeling &.. & $\cdots$ & $\ldots$ & 6,912 & & 23.436 & 472 & 449 & $3^{82}$ & 368 & 364 & 363 \\
\hline Goalpara & ... & $\ldots$ & $\ldots$ & $3^{86}$ & & $29.46 I$ & $\overline{593}$ & $64 \mathrm{I}$ & 610 & $\cdot 544$ & 459 & 383 \\
\hline Stratum & betw & $\mathrm{en}-\mathrm{th}$ & ckness & 6,526 & weight & 6.025 & $\cdot 121$ & $\cdot 192$ & .228 & 176 & .095 & 020 \\
\hline Ranikhet & $\ldots$ & $\ldots$ & $\ldots$ & 6,069 & & $24 \div 108$ & 180 & $\cdot 15^{8}$ & .079 & .070 & .055 & 070 \\
\hline Lucknow & $\cdots$ & .. & $\cdots$ & 369 & & 29.503 & .651 & .696 & $\cdot 64 \mathrm{I}$ & 596 & $48 \mathrm{I}$ & 348 \\
\hline Stratum & betw & $n-t h$ & kness & 5,700 & weight & t 5.395 & 471 & $\cdot 538$ & .562 & 526 & 426 & $\cdot 278$ \\
\hline Wellington & & $\ldots$ & $\ldots$ & 6,200 & & $24 \cdot 217$ & $\cdot 245$ & .256 & $\cdot 208$ & $\cdot 226$ & $\cdot 246$ & 247 \\
\hline Madras & $\cdots$ & $\cdots$ & $\cdots$ & 22 & & 29.847 & 922 & 965 & 944 & 921 & .895 & .843 \\
\hline Stratum & betw & $n-t$ & kness & 6,178 & weight & 5.630 & 677 & 709 & .736 & $\cdot 695$ & $\cdot 649$ & $\cdot 596$ \\
\hline
\end{tabular}

* To avoid repetition, I have merely given the decimals after the first column. In every instance of omission the last prefixed integer is to be supplied. generally admitted that the preceding facts not only dispose of $\mathrm{Mr}$. Broun's objection to the idea that pressure and temperature are related, because the epoch of maximum atmospheric pressure on the plains of India generally precedes that of minimum temperature, but also show how abortive any attempt to base inductions regarding a secular variation in solar heat, upon the results of comparing the annual range of monthly mean pressure, or even different parts of India, must necessarily prove, unless they be duly taken into consideration.

\section{Insect Galls Buds}

INSECT galls are held to be "excrescences"; a "diseased condition of vegetable tissue"; and they are supposed to result from the "injection of a fluid," or from some "secretion." The student may most easily begin an investigation of galls with the dissection of those produced by the turnip weevil (Curculio pleurostigma) on the bulb of the Swede. The roots of Swedish turnips are frequently covered with hundreds of irregular spherical warts, from $\mathrm{O} 3$ to 75 of an inch in diameter, growing either singly or crowded together in clusters. These warts are regarded by $M$. Woronin (Plasmodiophora brassice, Pringsheim's Fahrb. xi. B. p. 548) as resulting from the fungus which he has discovered to be the cause of club-rooting in cruciferous plants. I believe that on this point M. Woronin has been misled. The true clubs produced by his fungus are entirely distinct from these root-nodes. Under favourable conditions the root-nodes have been found to give rise to tufts of leaves; a fact which I can confirm by many examples presently growing in my possession. Dissection of these nodes, on Swedes, shows that they contain none of the plasma and spores which constitute the bulk of the true clubs. They are, in fact, tuberculated buds arising directly from medullary rays in the root to which they are attached. These can be traced through the enveloping parenchyma into the nodes, where they are seen to give rise to masses of contorted and branching leaves. The nodules within the bark of the beech, hazel, and other trees, are of the same character as those on the turnip. The medullary nexus of these nodules sometimes comes straight from the centre of the tree into the node, and sometimes runs along like a cord under. the outer layers of the bark, entering the node by the end.
Without going any deeper into the matter, it must, I think, be the mean annual pressure, for a number of years in succession in

With reference to:Mr. Broun's conclusions alone, the following monthly barometric weight of such a stratum in different part of the country, will show that the maximum invariably occurs in January, that is to say, it coincides with the epoch of minimum temperature. Two bars placed underneath a figure indicate the maximum pressure or weight of the year; one bar, the secondary maximum at the hill-stations in the spring. ${ }^{1}$ investigation.

I. The annual oscillations of monthly mean pressure and monthly mean temperature bear an exceedingly variable ratio to one another in India, such variation being a function partly of the altitude, and partly of the distance from the coast.

2. Non-coincidence of the critical epochs of monthly mean pressure and temperature, cannot be rigorously employed as an argument against the hypothesis, hitherto generally accepted, of a causal connection between them.

\section{E. Douglas Archibald}

modifications should be attached, according to the results of my

Iet a dissection now be made of one of the weevil galls on the bulb of the turnip. The second or third slice will show the outer foliations, exactly similar to those of the root buds. When the centre has been reached, where the maggot will be found, there will also be found a vascular pencil running up from a medullary ray in the bulb, and bearing on its top a bud of the same description as that prcduced by a ray running out from a root. The insertion of the ovipositor brings a medullary ray into action, producing a tuberculated bud, and it is only the bud which the larva feeds upon. The growth of a bud is an intelligible cause of the growth of a gall, but we can infer nothing from the injection of a fluid.

All insect galls are in reality leaf-buds, or fruit-buds. They are not mere amorphous excrescences. The vascular lines which would form leaves can easily be followed up the structure of the oak.leaf galls. And in cases where the egg has been deposited in the tissue of a young branch the cap of the gall is sometimes surmounted by a leaf two or three inches long. But in the large blue Turkish galls many lacunæ occur where the fleshified leaves have not filled up the spaces between them. The morphology of the hollow woody shell, and its inclosures of starch, \&c., found in the interior of these galls I hope to work out by and by. It is a curious fact that various microscopic fungi are matured in the interior of imperforate galls.

A. STEPHEN WILSON

North Kinmundy, Aberdeen

1 In selecting the particular station on the plains to be used in each case,

have endeavoured as far as possible to fulfil two renuisites: $(x)$ proximity to the hill-station, (2) low elevation above sea-level. 